\title{
Review
}

Kawaljit Singh Randhawa* and Ashwin D. Patel

\section{A review on tribo-mechanical properties of micro- and nanoparticulate-filled nylon composites}

https://doi.org/10.1515/polyeng-2020-0302

Received November 6, 2020; accepted February 20, 2021;

published online March 15, 2021

Abstract: Nylon composites are of evolving interest due to their good strength, toughness, and low coefficient of friction. Various fillers like micro- and nanoparticulates of metals and metal compounds were used to enhance the mechanical and tribological properties of nylons for many years by researchers. In this paper, an overall understanding of composites, filler materials, especially particulate filler materials, application areas of polymer composites, wear of polymers, and the effect of various fillers on tribomechanical properties of nylons have been discussed. The detailed review is limited to micro- and nanoparticulate fillers and their influence on the mechanical and tribological properties of various nylon matrices.

Keywords: friction; mechanical properties; nylon composite; tribological properties; wear.

$\begin{array}{ll}\text { Nomenclature } \\ \mathrm{ABS} & \text { Acrylonitrile butadiene styrene } \\ \mathrm{Al}_{2} \mathrm{O}_{3} & \text { Aluminum oxide } \\ \mathrm{CaF}_{2} & \text { Calcium fluoride } \\ \mathrm{CaO} & \text { Calcium oxide } \\ \mathrm{COF} & \text { Coefficient of friction } \\ \mathrm{CuF} & \text { Cuprous fluoride } \\ \mathrm{CuO} & \text { Copper oxide } \\ \mathrm{CuS} & \text { Copper sulfide } \\ \mathrm{GRF} & \text { Graphite fluoride } \\ \mathrm{GRP} & \text { Glass(fiber) reinforced plastic } \\ \mathrm{HDPE} & \text { High-density polyethylene } \\ \mathrm{HNT} & \text { Halloysite nanotubes } \\ \text { LDPE } & \text { Low-density polyethylene } \\ \text { MoS } & \text { Molybdenum sulfide } \\ \text { MoS } & \text { Molybdenum disulfide }\end{array}$

*Corresponding author: Kawaljit Singh Randhawa, Mechanical Engineering Department, CSPIT, CHARUSAT University, Changa, Anand 388421, Gujarat, India,

E-mail: kawaljitrandhawa.me@charusat.ac.in. https://orcid.org/ 0000-0002-2944-6714

Ashwin D. Patel, CSPIT, CHARUSAT, Changa 388421, Gujarat, India

$\begin{array}{ll}\text { MWNT } & \text { Multiwalled carbon nanotube } \\ \mathrm{PbS} & \text { Lead sulfide } \\ \mathrm{PEEK} & \text { Polyether ether ketone } \\ \mathrm{PTFE} & \text { Polytetrafluoroethylene } \\ \mathrm{SiO}_{2} & \text { Silicon dioxide } \\ \mathrm{UHMWPE} & \text { Ultra-high-molecular-weight polyethylene } \\ \mathrm{ZnF}_{2} & \text { Zinc fluoride } \\ \mathrm{ZnO} & \text { Zinc oxide } \\ \mathrm{ZnS} & \text { Zinc sulfide } \\ \mathrm{ZrP} & \text { Zirconium phosphate }\end{array}$

\section{Introduction}

A composite is a material that consists of two or more chemically different constituents that are combined at a macroscopic level and are not soluble in each other to yield a useful material. Composite materials have been widely applied in various applications like aeronautical industries, biomechanics, public infrastructure, automobile industries, furniture. Composites have unique advantages over many monolithic materials, such as high strength, high stiffness, longer fatigue life, low density, and adaptability to the intended functions of the structure [1-8].

A few examples of composites are shown in Table 1.

There are several benefits of composites mentioned as follows:

- Light weight: composites can be made light in weight to replace any heavier material. Their lightness is important in automobiles and aircraft, for example, where less weight means better fuel efficiency. People who design airplanes are greatly concerned with weight since reducing an air craft's weight reduces the amount of fuel it needs and increases the speeds it can reach.

- High strength: composites can be designed stronger. Metals are equally strong in all directions, but composites can be engineered and designed to be strong in a specific direction.

- Strength to weight ratio: strength to weight ratio is a material's strength to how much it weighs. Some materials are extraordinarily strong and heavy, such as steel and other metals. Composite materials can be 
designed to be both strong and light. This property is why composites are used to build airplanes, which need a remarkably high strength material at the lowest possible weight. A composite can be made to resist bending in one direction.

- Corrosion resistance: composites resist damage from the weather and harsh chemicals. Composites can be used where chemicals are handled or stored. Composites can be used in humid areas. It can be used in an open rainy atmosphere.

- High-impact strength: composites can be made to absorb impacts like the sudden force of a bullet, for instance, or the blast from an explosion. Because of this property, composites are used in bulletproof vests and panels, and to shield airplanes, buildings, and military vehicles from explosions.

- Low thermal conductivity: composites are good insulators. They do not easily conduct heat or cold. They are used in buildings for doors, panels, and windows where extra protection is needed from severe weather.

- Durability: structures made of composites have a long life and need less maintenance. Composites can replace other materials where durability is the main issue.

- Nonconductivity: Most of the composites are nonconductive, meaning they do not conduct electricity. This property makes them suitable for such items as electrical utility poles and circuit boards in electronics. If electrical conductivity is needed, it is possible to make some composites conductive.

- Wear resistance

- Fatigue life

- Acoustic insulation

- Attractiveness

- Damping properties: composite materials can be engineered to get the desired damping properties.

- Temperature resistance.

And composites have many more advantages. Composites can be made to fulfill the requirements of properties that only one single material cannot fulfill. Current application areas of engineered composites are shown in Table 2.

Table 1: Natural and engineered composites.

\begin{tabular}{ll}
\hline Natural composites & Manmade/engineered composites \\
\hline Wood (fibrous composite) & Concrete (particulate composite) \\
Bone (fibrous composite) & Plywood (fibrous composite) \\
Granite (particulate composite) & Fiberglass (short fibrous composite) \\
\hline
\end{tabular}

Apart from all these, composites are also used in consumer goods products, agriculture, computer hardware, and many more places.

Composites can be classified according to the:

- Matrix material used

- Reinforcing element used, and

- The orientation of fibers/particles and numbers of layers.

A few examples of available matrix materials are shown in Table 3.

Depending on the matrix material used, composites are classified as thermoplastic/thermoset matrix composite, metal matrix composite, and ceramic matrix composite.

A few general properties of matrix materials are mentioned in Table 4.

Following are the functions of matrix materials:

- Holds the fillers

- Protects the reinforcing particles/fillers from contamination

- Helps to maintain the distribution of fillers

- Distributes the loads evenly

- Enhances some of the properties of the resulting material and structural component (that filler alone is not able to impart) such as tensile strength, impact resistance

- Provides a better finish to the final product.

- Supports the overall structure.

Reinforcing elements may be in the form of particles, flakes, or whiskers. According to that, the following are the classifications of reinforcements:

- Fiber reinforced: in which, length to diameter ratio is remarkably high (of the order 1000). Continuous fibers are essentially characterized by one exceptionally long axis with the other two axes either often circular or near-circular. A composite with fiber reinforcement is called a fibrous composite.

- Particle reinforced: in which particles are used as reinforcement. These particles do not have any long dimensions. Generally, particles have neither preferred orientation nor shape. A composite with particles as reinforcement is called a particulate composite.

Flake reinforced: flakes are small in length direction compare to continuous fibers.

- Whisker reinforced: whiskers are nearly perfect single crystal fiber. Whiskers are short, discontinuous, and have a polygonal cross-section. 
Table 2: Application areas of engineered composites.

\begin{tabular}{llllll}
\hline Automotive sector & Aerospace sector & Sports & Transportation & Infrastructure & Biomedical industry \\
\hline Car body & Nose & Tennis rackets & Railway coaches & Dams & Artificial legs \\
Brake pads & Aircraft, rocket, and missile body & Hockey sticks (glass fiber & Ships & Bridges & Dentistry \\
Driveshafts & Doors & composite) & Trucks & Artificial joints \\
Fuel tank & Struts & Bikes & & \\
Hoods/bonnet & Trunnion & Boats & & \\
Spoilers & Fuel tanks & Golf & & \\
& Satellite frames and other & & & \\
& structural parts & & & \\
& Antenna (smart materials) & & & \\
\end{tabular}

Table 3: Matrix materials.

\begin{tabular}{|c|c|c|c|}
\hline Thermoplastics & Thermosets & Metals & Ceramics \\
\hline Polypropylene & Polyesters & Aluminum & Carbon \\
\hline Polyvinyl chloride (PVC) & Epoxies & Titanium & $\begin{array}{l}\text { Silicon } \\
\text { carbide }\end{array}$ \\
\hline Nylon & Polyimides & Copper & Silicon nitride \\
\hline Polyurethane & & Tin & \\
\hline \multirow{2}{*}{\multicolumn{4}{|c|}{$\begin{array}{l}\text { Poly-ether-ether ketone } \\
\text { (PFEK) }\end{array}$}} \\
\hline & & & \\
\hline Polyphenylene sulfide (PPS) & & & \\
\hline
\end{tabular}

Table 4: General properties of matrix materials.

\begin{tabular}{|c|c|c|}
\hline $\begin{array}{l}\text { Thermoplastics/ } \\
\text { thermosets }\end{array}$ & Metals & Ceramics \\
\hline $\begin{array}{l}\text { Operating } \\
\text { temperature range } \\
<300^{\circ} \mathrm{C}\end{array}$ & $\begin{array}{l}\text { Higher use operating } \\
\text { temperature range } \\
\left(>200^{\circ} \mathrm{C} \text { up to } 1500^{\circ} \mathrm{C}\right. \\
\text { and more) }\end{array}$ & $\begin{array}{l}\text { Extremely } \\
\text { high-temperature } \\
\text { range }>2000^{\circ} \mathrm{C} \\
\text { (most cases) }\end{array}$ \\
\hline Lighter & Heavier & Heavier \\
\hline $\begin{array}{l}\text { Low moisture } \\
\text { absorption }\end{array}$ & No moisture absorption & $\begin{array}{l}\text { Low moisture } \\
\text { absorption }\end{array}$ \\
\hline Low-cost processing & High-cost processing & $\begin{array}{l}\text { High-cost } \\
\text { processing }\end{array}$ \\
\hline $\begin{array}{l}\text { Heat resistance is } \\
\text { less }\end{array}$ & Good heat resistance & $\begin{array}{l}\text { High heat } \\
\text { resistance }\end{array}$ \\
\hline $\begin{array}{l}\text { Cold and hot } \\
\text { moulding }\end{array}$ & Hot moulding & Hot moulding \\
\hline Low cost & High cost & High cost \\
\hline $\begin{array}{l}\text { Mechanical strength } \\
\text { is less }\end{array}$ & $\begin{array}{l}\text { Good mechanical } \\
\text { strength }\end{array}$ & $\begin{array}{l}\text { Good mechanical } \\
\text { strength }\end{array}$ \\
\hline $\begin{array}{l}\text { Average chemical } \\
\text { resistance }\end{array}$ & $\begin{array}{l}\text { Average chemical } \\
\text { resistance }\end{array}$ & $\begin{array}{l}\text { High chemical } \\
\text { resistance }\end{array}$ \\
\hline
\end{tabular}

Depending on the reinforcing element used, composites are classified as fiber reinforced composite, particle reinforced composites, flake reinforced composite and whisker reinforced composite. Reinforcing constituents in composites, as the word indicates, provide the strength that makes the composite what it is. But they also serve certain additional purposes of heat resistance or conduction, corrosion resistance, and provide rigidity. Reinforcement can be made to perform all or one of these functions as per the requirements. A reinforcement that embellishes the matrix strength must be stronger and stiffer than the matrix and capable of changing the failure mechanism to the advantage of the composite. Briefly, it must

- Contribute desired properties

- Be load-carrying

- Transfer the strength to the matrix.

Figure 1 shows the classification according to the orientation of fibers/particles and the layers.

\subsection{Classifications of particulate fillers}

Various metals and metal compounds are used as the filler materials for enhancing the tribo-mechanical properties of polymers.

(1) Metals: metal particles like aluminum, copper, iron, boron, lead, bronze are used as the fillers in polymer matrices to enhance the required properties of polymers.

(2) Metal compounds: metal compounds like oxides, nitride, carbides, and fluorides are generally in application to enhance the properties of matrix polymer materials. Metal carbides tend to increase the COF but ultimately reduce the wear rate due to their abrasive nature. Various metal compounds are used as solid lubricants as they develop a smooth transfer layer on the counterparts which decreases $\mathrm{COF}$ as well as the wear rate of the polymer part. Solid lubricants are classified as:

a) Inorganic lubricants with lamellar structure: the crystal of these materials has a layered structure that consists of hexagonal rings and forms thin parallel planes. Within the plane, each atom is 
bonded strongly while the planes are bonded by weak Van der Waals forces to each other. The layered structure gives the sliding movement of the parallel planes. Weak bonding between the planes gives low shear strength and lubricating properties to the materials. The commonly used inorganic solid lubricants with lamellar structure are graphite, molybdenum disulfide $\left(\mathrm{MoS}_{2}\right)$, and boron nitride (BN). Other examples are sulfides, selenides and tellurides of molybdenum, tungsten, niobium, tantalum, titanium (e.g. $\mathrm{MoSe}_{2}, \mathrm{TaSe}_{2}, \mathrm{TiTe}_{2}$ ), monochalcenides ( $\mathrm{GaS}, \mathrm{SnSe}$ ), chlorides of cadmium, cobalt, lead, zirconium (e.g. $\mathrm{CdCl}_{2}, \mathrm{CoCl}_{2}, \mathrm{PbCl}_{2}$, $\mathrm{CeF}_{3}$ ) and some borates (e.g. $\mathrm{Na}_{2} \mathrm{~B}_{4} \mathrm{O}_{7}$ ) and sulfates $\left(\mathrm{Ag}_{2} \mathrm{SO}_{4}\right)$.

b) Oxides: examples: boron trioxide $\left(\mathrm{B}_{2} \mathrm{O}_{3}\right)$, molybdenum dioxide $\left(\mathrm{MoO}_{2}\right)$, zinc oxide $(\mathrm{ZnO})$, and titanium dioxide $\left(\mathrm{TiO}_{2}\right)$.

c) Soft metals: due to their low shear strength and high plasticity these soft metals provide lubrication properties, e.g., lead $(\mathrm{Pb})$, tin $(\mathrm{Sn})$, bismuth (Bi), cadmium (Cd), and silver (Ag).

d) Organic lubricants with the chain structure of the polymeric molecules: polytetrafluoroethylene (PTFE) and polychlorofluoroethylene are examples of such kinds of materials. The molecular structure

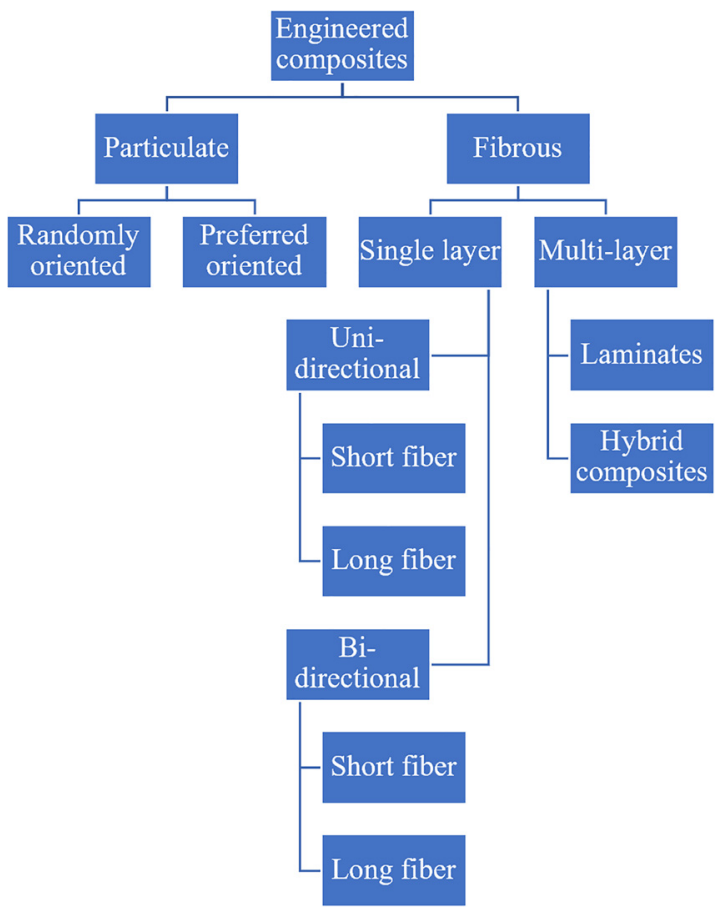

Figure 1: Classification of composites according to orientation of fibers/particles and numbers of layers. of these materials consists of long-chain molecules parallel to one another. The bonding strength between the molecules is weak so they slide on each other at low shear stresses while the strength of molecules along the chains is high because of strong bonding between the atoms within a molecule.

Table 5 represents the merits and demerits of polymers with the additives and their effects on the mechanical as well as on the tribological properties of polymers. The main question with the use of solid lubricants is to maintain a continuous supply of solid lubricants between two sliding surfaces. The best answer to this question is to introduce the solid lubricant as reinforcement into the matrix. A self-lubricating material is one whose composition facilitates low coefficients of friction and wear. Composites reinforced by solid lubricants become selflubricating due to the lubricant film which prevents direct contact between the mating surfaces. This lubricant film is not present at the beginning, it forms due to the surface wear of solid lubricant reinforced composite material.

Self-lubrication can be produced by:

- Interface sliding of anisotropic materials such as graphite, molybdenum disulfide, or diselenides

- Inter-chain sliding in linear thermoplastics like polytetrafluoroethylene or polyolefins

- Surface melting of fusible elements like lead, tin, or polyethylene

- Surface thermal decomposition of metal-containing chemical compounds like oxalates of metals.

Table 5: Polymer merits, demerits, additives, and their effects [9].

\begin{tabular}{|c|c|c|c|}
\hline Merits & Demerits & Additives & Effects \\
\hline $\begin{array}{l}\text { Low friction \& } \\
\text { wear }\end{array}$ & Low strength & PTFE & $\begin{array}{l}\text { Reduce friction \& } \\
\text { wear }\end{array}$ \\
\hline $\begin{array}{l}\text { No tendency to } \\
\text { seizure }\end{array}$ & $\begin{array}{l}\text { Low thermal } \\
\text { conductivity }\end{array}$ & $\begin{array}{l}\text { Lamellar } \\
\text { solids }\end{array}$ & \\
\hline $\begin{array}{l}\text { Easily } \\
\text { fabricated }\end{array}$ & $\begin{array}{l}\text { High thermal } \\
\text { expansion }\end{array}$ & Inorganics & Reduce wear \\
\hline Less costly & $\begin{array}{l}\text { Poor dimensional } \\
\text { stability }\end{array}$ & Fibers & $\begin{array}{l}\text { Improve } \\
\text { mechanical } \\
\text { properties, } \\
\text { reduce wear }\end{array}$ \\
\hline $\begin{array}{l}\text { Varieties } \\
\text { available }\end{array}$ & $\begin{array}{l}\text { Poor chemical } \\
\text { stability }\end{array}$ & Metals & $\begin{array}{l}\text { Improve } \\
\text { mechanical \& } \\
\text { thermal } \\
\text { properties }\end{array}$ \\
\hline $\begin{array}{l}\text { Blending of } \\
\text { polymers is } \\
\text { possible (not } \\
\text { all) }\end{array}$ & $\begin{array}{l}\text { Some polymers } \\
\text { absorb moisture } \\
\text { from the } \\
\text { environment }\end{array}$ & & \\
\hline
\end{tabular}


Graphite and polyethylene form lubricating layers of friction transfer on the mated surfaces during friction and due to this, it provides low resistance to relative motion and high wear resistance. At temperatures above $100{ }^{\circ} \mathrm{C}$ local meltings of polyethylene takes place, and it functions as a highly viscous lubricant [10]. Self-lubricating polymer composites are widely used in space applications where timely preventive maintenance is not possible [11]. Also, they are widely used in cryogenic bearings where liquid lubrication of parts is not possible. The application areas are increasing day by day because of its unique ability of self-lubrication which will eliminate the usage of external lubrication requirements.

\section{Wear of polymers}

The wear of polymers is influenced by three groups of parameters in which the first group includes the sliding contact conditions like surface roughness and contact kinematics. The second group includes the bulk mechanical properties of the polymer and the effect of temperature and environmental conditions on these properties. The third group involves the role and properties of the 'third body' i.e. the transfer film and loose degraded polymer particulates. The wear mechanism and its magnitude are defined by the contract conditions, mechanical properties of the bulk polymer, and how these parameters lead to the subsequent transfer film formation and debris production. The following Figure 2 represents the wear classification based on generic scaling, phenomenological, and material response approaches [12].

Few studies show that polymer wear in the presence of external lubricants will depend primarily upon the interaction between the fluid phase and the polymer and on their counter face. Except where there is sorption of the lubricant by the polymer surface, generally, polymer wear

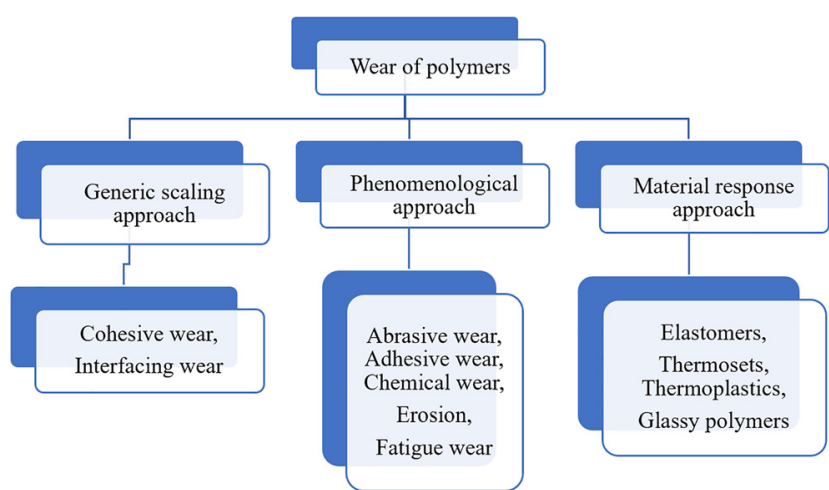

Figure 2: Classification of the wear of polymers. has been seen high in the presence of an external fluid. According to one study, the friction force is proportional to the normal applied load i.e. $F_{\mathrm{f}}=\mu \mathrm{Fn}$. Where $F_{\mathrm{f}}$ is friction force, $\mu$ is the coefficient of friction and Fn is the normal force or normal load. The friction coefficient remains constant in the range 10-100 $\mathrm{N}$ load. It was noticed that in the range of $0.02-1 \mathrm{~N}$ load, the friction coefficient decreases with increasing the load [13], and the friction coefficient increases with increasing the load on the other side. This is due to the plastic deformation of asperities that are in contact. Polymers are viscoelastic materials and extremely sensitive to frictional heating. Due to friction, mechanical energy is converted into heat which raises the temperature at contact and makes an influences the wear of polymers. It was observed that many polymers sliding against steel exhibit minimum wear rates at characteristic temperatures. The product of the elongation to break $(\epsilon)$ and the breaking strength (S) are important parameters in the wear of polymers. $1 / S \epsilon$ varies with temperature in the same way as the wear rate varies. In abrasive wear, the wear rates of many polymers show an approximately linear correlation with 1/Se [14]. The most common types of wear of polymers are abrasion, adhesion, and fatigue. The wear mechanisms of the polymer composites show that micro composites tend to suffer from abrasive wear while nanocomposites suffer from adhesive wear while observing the wear tracks on scanning electron microscopy (SEM) [15].

To provide lubrication, the material must be able to support dynamic stresses induced by the applied load and the tangential friction stresses. If the polymer/polymer composite cannot support these stresses then it will plastically deform, undergo brittle fracture, and ultimately wear quickly. To provide the best lubrication, a thin shear layer must develop between the sliding surfaces. This shear layer is important to reduce the adhesive and the ploughing interactions which take place between surfaces moving relative to each other. A thinner shear layer is found to be better in general compared to a thick layer. Table 6 represents some self-lubricating composites and their possible uses in space [16]. Table 7 shows some commercially available materials for bearings [17].

Table 6: Some self-lubricating composites and their uses in space.

\begin{tabular}{ll}
\hline Composite type & Use \\
\hline PTFE and glass fiber & Bearing cages \\
PTFE, glass fiber and $\mathrm{MoS}_{2}$ & Bearing cages and gears \\
Polyacetal homopolymer and & Bearing cages and gears \\
copolymer & Bushings and brakes \\
Reinforced phenolics & Bearing cages and gears \\
Polyimide and $\mathrm{MoS}_{2}$ & Bearing cages and gears etc. \\
\hline
\end{tabular}


Table 7: Commercially available materials for bearings.

\begin{tabular}{ll}
\hline Thermoplastics & PTFE/bronze-filled polyacetal \\
& Moulded or cast $\mathrm{MoS}_{2}$-filled nylons \\
& Porous (oil-filled) or solid $\left(\mathrm{MoS}_{2}\right.$-filled) nylon \\
& Oil-filled nylons \\
& Oil-filled polyacetal \\
& Steel-backed porous bronze with oil-filled \\
polyacetal & PTFE/glass fiber/oil-filled thermoplastics \\
Thermosets & Graphite/MoS M $_{2}$-filled thermoset \\
& Asbestos fiber reinforced thermoset \\
& Cotton fabric reinforced thermoset
\end{tabular}

In one research, glass fibers were used to reinforce an epoxy to which additives of PTFE, graphite, and molybdenum disulfide were used to produce a self-lubricating material. The composite of glass fibers reduced the coefficient of friction value to as low as 0.02 [18]. Graphite in epoxy composite reduced the coefficient of friction and improved the wear resistance of the material to a good extent in Xiubing Li et al.'s experimentation [19]. In another experiment, $16 \mathrm{MnNb}$ steel-PTFE composite (A) containing 60\% area proportion of PTFE composite and C86300 bronzePTFE composite (B) containing 35\% area proportion of PTFE composite were developed for a comparative investigation. As the result, composite A exhibited a much low coefficient of friction and high wear resistance as compared to composite $B$ had been found due to the area proportion of solid lubricant for composite A reached $60 \%$, which provided sufficient lubrication during the whole tests [20]. According to the study of Debnath et al., increasing the strength of the bond between filler and matrix will not improve the mechanical properties of particulate-reinforced composites compare to fiber reinforced composites [21]. Also, the wear rates of materials, in general, are related to the ratio of the indentation hardness (H) to elastic modulus (E). The lower the ratio $\mathrm{H} / \mathrm{E}$, the greater the rate of wear. Fibers and particle reinforcements are generally advantageous in reducing friction coefficient and wear rate in dry conditions rubbing with the smooth surface while in the case of abrasive wear, these reinforcements generally increase it. One research stated that the carbon, graphite, molybdenum disulfide $\left(\mathrm{MoS}_{2}\right)$, polytetrafluoroethylene (PTFE) and short glass fibers increased the abrasive wear of polymers [22]. One study revealed that the $10 \mathrm{wt} \%$ of $\mathrm{h}-\mathrm{BN}$ resulted in a minimum specific wear rate of polyether ketone while $3 \mathrm{wt} \%$ of neodymium oxide addition enhanced the microhardness by $17 \%$ and resulted in lower abrasion [23, 24].

Two-dimensional materials generally have higher elastic properties when used in small amounts in comparison to the corresponding bulk quantity. And because of that, the mechanical properties of 2D materials have been found to decrease with increasing content of it [25]. Boric anhydride is used by many researchers to improve the mechanical properties of materials. For example, $5 \mathrm{wt} \%$ of boric anhydride improved micro-hardness and strength of hydroxyapatite $\left(\mathrm{Ca}_{10}\left(\mathrm{PO}_{4}\right)_{6}(\mathrm{OH})_{2}\right)$ which is used in human hard tissue implants [26]. In one research, $10 \mathrm{~mol} \%$ of boric anhydride improved bending strength and Rockwell hardness of diamond composite [27]. While the mechanical properties of the phosphate-based glass fibers continuously increased with increasing boric anhydride content [28].

\section{Nylon and nylon particulate composites}

Nylons are an especially important part of the thermoplastic polymer family and having different subtypes like nylon 6 , nylon 66, nylon 11, nylon 1010. Nylons are also known as polyamides (PA) due to their repeating units linked by amide links. Nylons are tough, possessing high tensile strength, as well as elasticity and luster. They are wrinkleproof and highly resistant to abrasion and chemicals such as acids and alkalis. Some nylons can absorb up to $2.4 \%$ of water, although this lowers tensile strength. There are various fabrication techniques developed by the researcher to make nylon composites in which two methods as follows are widely known and effective.

\subsection{Fabrication of nylon particulate composites}

The dispersion of micro-/nanoparticulates in a nylon matrix is an important step in the synthesis of nylon composites. A well-dispersed filler ensures a good surface area which affects the properties of nylon matrices. Generally, two methods are widely used for the compounding purpose and these are in situ polymerization and melt blending.

\subsubsection{In situ polymerization}

In situ polymerization is a widely used technique for the compounding of micro- and nanoparticulate-filled nylon composites. Other widely used polymers in this method are, for example, epoxy, polystyrene, acrylic, polyurethane, polyethylene, polyimide. There are two steps in this method, First, the fillers are mixed with the monomers, and then in the second step, a suitable initiator is diffused in for polymerization at adjusted temperature for a suitable 
time. In situ techniques are more popularly used for nanocomposite fabrication with nanoparticulate fillers like graphene, graphene oxide. In this method there are two routes, one is ionic ring-opening polymerization and the second one is hydrolytic polymerization. Xu et al. have prepared nylon 6/graphene oxide composite with the help of in situ polymerization technique. Graphene oxide was first dried and then thermally reduced to graphene and they found improvement in the mechanical properties of composite compare to pure nylon 6 [29]. Liu et al. fabricated nylon 6/functional graphene composite by this method. Nylon 6 chains were grafted on functional graphene and enhancement in mechanical properties of the composites was found compare to pure nylon 6 [30]. Ding et al. prepared nylon 6/graphene oxide nanocomposite by in situ technique. Graphene oxide was reduced to graphene at $250{ }^{\circ} \mathrm{C}$ and it improved the thermal conductivity of the base matrix material [31].

\subsubsection{Melt blending}

Melt blending is a more commercially used method for compounding micro- or nanoparticulates with thermoplastic polymers. Various thermoplastic polymers are used in melt blending like nylon, PEEK, LDPE, HDPE, polystyrene, polyurethane, polyethylene, polypropylene. It is the most suitable method for mass production. In this method, fillers are initially mixed mechanically with the matrices and then fed into the single screw or twin-screw extruder or directly injection moulded with the help of an injection moulding machine. Screw speed, temperature, and time of extruder or injection moulding machine are selected according to the matrix materials and fillers used.

\subsection{Tribo-mechanical properties of nylon composites}

Nylons are used in many commercial \& industrial applications like bearings, gears, slides, toys, ropes, toothbrushes, household equipment, food packaging. But it cannot be used where excessive loads are applied and excessive wear are the main causes of failure due to low strength, hardness, and high wear rates compared to metals [32]. To achieve better mechanical and tribological properties, various micro- and nanoparticulate fillers have been used by the researchers like, copper, copper oxide, copper fluoride, graphite, molybdenum disulfide, silica, lead sulfide, copper sulfide, calcium sulfide, calcium oxide, long carbon nanotubes, silicon carbide, graphite fluoride, fluorographene, almond skin powder, magnesium hydroxides, boric anhydride, aluminum oxide, halloysite nanotube, nanotitanium dioxides [33-50]. Various fibers were also used to improve the tri-mechanical properties of polymers. Basalt, bamboo, pineapple-like natural, and glass \& carbon fiber-like manmade fibers were used by the researchers to improve the tribo-mechanical properties of the base polymer material [51-54]. In one research, $1 \mathrm{wt} \%$ diamond nanoparticles improved the friction coefficient and wear resistance by 60 and 30\%, respectively of nylon 6 [55]. Haoyang Sun et al. used alpha-zirconium phosphate nanoplatelets and in their result, they found improvement in mechanical and tribological properties of nylon 66 up to several percentages [56]. Nylon $66 / \mathrm{Al}_{2} \mathrm{O}_{3}$ micro-composites were fabricated with the help of a twin-screw extruder by Lalit Guglani and TC Gupta. Filler $\%$ varied from 2 to $8 \mathrm{wt} \%$ in their study. In their results, they found that the friction coefficient and wear rates reduced with the filler addition and found the lowest for the $2 \mathrm{wt} \% \mathrm{Al}_{2} \mathrm{O}_{3}$ reinforcement. Tensile strength, elastic modulus, flexural strength, and flexural modulus were also found to improve and the best values were found for $6 \mathrm{wt} \%$ $\mathrm{Al}_{2} \mathrm{O}_{3}$ filler reinforcement. Compressive and impact strength were enhanced and found maximum for the $6 \mathrm{wt} \%$ filler [57]. Nylon $6 / \mathrm{Al}_{2} \mathrm{O}_{3}$ nanocomposite was prepared with the in situ polymerization by Li-Yun-Zheng et al. Tensile strength of $3 \mathrm{wt} \%$ nanocomposite was found $52 \%$ more than the pure nylon 6 [58]. CaO nanoparticles of $0.5 \mathrm{wt} \%$ were introduced in the nylon 6 matrix by W. S. Mohamed et al. by the extrusion process. The tensile strength of the composite was investigated for the materials and it found a 57.35\% increased for the composite material compare to pure nylon 6 [59]. Nylon $6 / \mathrm{SiO}_{2}$ nanocomposites were fabricated with the help of single screw extrusion by Hasan et al. Nanoparticles with the wt $\%$ of $1 \& 2$ were introduced into the nylon 6 matrix and 26\% enhancement in tensile strength was observed for the composite material compare to pure nylon 6 [60]. Nylon 6 composites with different fillers like kaolin, talc, glass beads, and wollastonite at $10-30 \mathrm{wt} \%$ were fabricated with an injection moulding machine by Unal et al. These composites were fabricated with individual fillers as well as with the mixing of two. Tensile strength and flexural strength were found to improve as the content of filler increased in the matrix. Maximum tensile strength, flexural strength, and impact strength were found for $20 \mathrm{wt}$ $\%$ talc and wollastonite fillers mixture in the nylon 6 matrix [61]. Nylon 6/clay nanocomposite was fabricated using the melt intercalation technique by Mohanty and Nayak. In their result, they found the optimum performance for nylon 6 composite with $5 \mathrm{wt} \%$ nano clay loading [62]. Nylon 6/MWNT composite was prepared by Wei De Zhang et al. with the help of a twin-screw extruder and they found 
Table 8: Various polymers, reinforcement, and reinforcements' effects.

\begin{tabular}{|c|c|c|c|c|c|c|}
\hline \multirow[t]{2}{*}{ Polymer matrix } & \multicolumn{2}{|c|}{ Reinforcement } & \multirow{2}{*}{$\begin{array}{l}\text { Fabrication } \\
\text { process }\end{array}$} & \multirow{2}{*}{$\begin{array}{l}\text { Effect on the } \\
\text { mechanical } \\
\text { properties }\end{array}$} & \multirow{2}{*}{$\begin{array}{l}\text { Effect on COF \& } \\
\text { wear rate }\end{array}$} & \multirow[t]{2}{*}{ Any other effect } \\
\hline & Type & wt $\%$ & & & & \\
\hline Nylon 66 & $\mathrm{Al}_{2} \mathrm{O}_{3}$ microparticles & $\begin{array}{l}2,4,6 \& \\
8 w t \%\end{array}$ & $\begin{array}{l}\text { Twin screw } \\
\text { compounding }\end{array}$ & $\begin{array}{l}\text { Up to } 6 \text { wt } \% \\
\text { increased then } \\
\text { decreased }\end{array}$ & $\begin{array}{l}\text { Lowest found at } \\
2 \mathrm{wt} \%\end{array}$ & - \\
\hline LDPE & $\begin{array}{l}\text { Al, } \mathrm{Cu}, \mathrm{Fe} \text {, bronze } \\
\text { microparticles }\end{array}$ & $\begin{array}{l}10 \mathrm{wt} \% \\
\text { (anyone) }\end{array}$ & $\begin{array}{l}\text { Single-screw } \\
\text { compounding }\end{array}$ & $\begin{array}{l}\text { Reduction in } \\
\text { strength }\end{array}$ & - & $\begin{array}{l}\text { Increased thermal } \\
\text { diffusivity }\end{array}$ \\
\hline HDPE & Al flakes & $\begin{array}{l}5,10,15 \& \\
20 w t \%\end{array}$ & & & & \\
\hline$A B S$ & SS microparticles & $\begin{array}{l}10,15 \& \\
23 w t \%\end{array}$ & $\begin{array}{l}\text { Fused deposition } \\
\text { modeling }\end{array}$ & $\begin{array}{l}\text { Up to } 15 \% \text { same as } \\
\text { pure then decreased }\end{array}$ & - & $\begin{array}{l}\text { Enhancement in } \\
\text { glassy behavior } \\
\text { up to } 15 \%\end{array}$ \\
\hline Nylon & Iron particles & $\begin{array}{l}\text { - (increasing } \\
\text { order) }\end{array}$ & $\begin{array}{l}\text { Single screw } \\
\text { extrusion and } \\
\text { FDM }\end{array}$ & - & - & $\begin{array}{l}\text { Increase in ther- } \\
\text { mal conductivity }\end{array}$ \\
\hline Polystyrene & Nickel & 0 to 25 wt $\%$ & Brabender mixer & - & - & $\begin{array}{l}\text { Improved melting } \\
\text { point }\end{array}$ \\
\hline & Iron & & & Improved & & $\begin{array}{l}\text { Improved elec- } \\
\text { trical properties }\end{array}$ \\
\hline Nylon 6 & Al particles & 0 to 80 wt $\%$ & $\begin{array}{l}\text { Compression } \\
\text { moulding }\end{array}$ & $\begin{array}{l}\text { Decrease initially } \\
\text { then increased }\end{array}$ & - & - \\
\hline Epoxy & Silicon carbide particles & - & - & $\begin{array}{l}\text { Continuous incre- } \\
\text { ment in hardness }\end{array}$ & - & - \\
\hline Nylon 11 & Silica nanoparticles & $2,4 \& 6 w t \%$ & $\begin{array}{l}\text { Selective laser } \\
\text { sintering (SLS) }\end{array}$ & $\begin{array}{l}\text { Decrease in } \\
\text { compressive } \\
\text { modulus at } 2 \% \text { and } \\
\text { then it increase }\end{array}$ & - & - \\
\hline Nylon 6 & $\mathrm{CaO}$ nanoparticles & 0.5 wt $\%$ & $\begin{array}{l}\text { Twin screw } \\
\text { compounding }\end{array}$ & $\begin{array}{l}\text { Tensile strength } \\
\text { increased }\end{array}$ & - & - \\
\hline Nylon 6 & $\mathrm{SiO}_{2}$ nanoparticles & $0,1 \& 2 w t \%$ & $\begin{array}{l}\text { Single screw } \\
\text { extrusion }\end{array}$ & $\begin{array}{l}\text { Ultimate tensile \& } \\
\text { yield strength, hard- } \\
\text { ening modulus } \\
\text { increased }\end{array}$ & - & $\begin{array}{l}\text { More thermally } \\
\text { stable }\end{array}$ \\
\hline Nylon 6 & $\mathrm{Al}_{2} \mathrm{O}_{3}$ nanoparticles & $3 w t \%$ & $\begin{array}{l}\text { In situ } \\
\text { polymerization }\end{array}$ & $\begin{array}{l}\text { Tensile strength } \\
\text { increased }\end{array}$ & - & $\begin{array}{l}\text { Glass transition } \\
\text { temperature } \\
\text { increased }\end{array}$ \\
\hline Nylon 6 & $\begin{array}{l}\text { Wollastonite, kaolin, talc } \\
\& \text { glass beads }\end{array}$ & 10 to $30 \mathrm{wt} \%$ & $\begin{array}{l}\text { Twin-screw } \\
\text { compounding }\end{array}$ & $\begin{array}{l}\text { Tensile \& flexural } \\
\text { strength improved } \\
\text { but impact strength } \\
\text { decreased }\end{array}$ & - & - \\
\hline Nylon 6 & Nano clay particles & $5 \mathrm{wt} \%$ & $\begin{array}{l}\text { Melt intercalation } \\
\text { technique }\end{array}$ & $\begin{array}{l}\text { Tensile \& flexural } \\
\text { strength improved }\end{array}$ & - & - \\
\hline Nylon 6 & Carbon nanotubes & $1 \mathrm{wt} \%$ & $\begin{array}{l}\text { Twin-screw } \\
\text { compounding }\end{array}$ & $\begin{array}{l}\text { Tensile strength \& } \\
\text { modulus, hardness } \\
\text { improved }\end{array}$ & - & - \\
\hline Nylon 6 & Graphene & $\begin{array}{l}0.1,0.3,0.5 \\
1,3 \& 5 \text { wt } \%\end{array}$ & $\begin{array}{l}\text { Twin screw } \\
\text { compounding }\end{array}$ & - & - & $\begin{array}{l}\text { Improved thermal } \\
\text { properties }\end{array}$ \\
\hline Nylon 6 & $\mathrm{SiC} \& \mathrm{Al}_{2} \mathrm{O}_{3}$ microparticles & - & $\begin{array}{l}\text { Single screw } \\
\text { extrusion \& FDM }\end{array}$ & $\begin{array}{l}\text { Tensile \& yield } \\
\text { strength, Young's } \\
\text { modulus improved }\end{array}$ & - & - \\
\hline HDPE & $\mathrm{SiO}_{2}$ microparticles & $2,4 \& 6 w t \%$ & $\begin{array}{l}\text { Twin screw com- } \\
\text { pounding \& } \\
\text { extrusion }\end{array}$ & $\begin{array}{l}\text { Increased Young's } \\
\text { modulus }\end{array}$ & - & - \\
\hline Nylon 6 & $\begin{array}{l}\text { Pristine } \alpha \text {-zirconium } \\
\text { phosphate nanoplatelets }\end{array}$ & $1,3 \& 5 w t \%$ & $\begin{array}{l}\text { Single screw } \\
\text { extrusion \& injec- } \\
\text { tion molding }\end{array}$ & $\begin{array}{l}\text { Increased tensile } \\
\text { modulus }\end{array}$ & - & - \\
\hline
\end{tabular}


Table 8: (continued)

\begin{tabular}{|c|c|c|c|c|c|c|}
\hline \multirow[t]{2}{*}{ Polymer matrix } & \multicolumn{2}{|c|}{ Reinforcement } & \multirow{2}{*}{$\begin{array}{l}\text { Fabrication } \\
\text { process }\end{array}$} & \multirow{2}{*}{$\begin{array}{l}\text { Effect on the } \\
\text { mechanical } \\
\text { properties }\end{array}$} & \multirow{2}{*}{$\begin{array}{l}\text { Effect on COF \& } \\
\text { wear rate }\end{array}$} & \multirow[t]{2}{*}{ Any other effect } \\
\hline & Type & wt\% & & & & \\
\hline Nylon 6 & Carbon nanotubes & $1 \mathrm{wt} \%$ & $\begin{array}{l}\text { Twin-screw } \\
\text { compounding \& } \\
\text { injection molding }\end{array}$ & $\begin{array}{l}\text { Increased tensile } \\
\text { strength }\end{array}$ & - & - \\
\hline PTFE & Boric oxide & - & $\begin{array}{l}\text { Compression } \\
\text { molding }\end{array}$ & - & $\begin{array}{l}\text { Reduction in } \\
\text { COF \& wear }\end{array}$ & - \\
\hline PTFE & Serpentine & $10 \mathrm{wt} \%$ & $\begin{array}{l}\text { Compression } \\
\text { molding }\end{array}$ & - & $\begin{array}{l}\text { Reduction in } \\
\text { COF }\end{array}$ & - \\
\hline Epoxy & Graphite & $\begin{array}{l}\text { Less than } \\
30 \text { vol\% }\end{array}$ & - & - & $\begin{array}{l}\text { Reduction in } \\
\text { COF \& wear }\end{array}$ & - \\
\hline & $\mathrm{MoS}_{2}$ & & & & $\begin{array}{l}\text { Reduction in } \\
\text { wear rate but } \\
\text { COF unchanged }\end{array}$ & \\
\hline & Graphite $+\mathrm{MoS}_{2}$ & & & & $\begin{array}{l}\text { Reduction in } \\
\text { COF \& wear }\end{array}$ & \\
\hline Epoxy & Woven carbon fiber & 30 vol\% & $\begin{array}{l}\text { Resin transfer } \\
\text { molding process }\end{array}$ & $\begin{array}{l}\text { Increased bending } \\
\text { strength }\end{array}$ & $\begin{array}{l}\text { Reduction in } \\
\text { COF \& wear }\end{array}$ & - \\
\hline Polyester & Glass fiber & 50 vol\% & - & - & $\begin{array}{l}\text { Reduction in } \\
\text { COF \& wear }\end{array}$ & - \\
\hline $\begin{array}{l}\text { Polyphenylene } \\
\text { sulfide }\end{array}$ & Carbon fiber & 50 vol\% & - & - & $\begin{array}{l}\text { Reduction in } \\
\text { wear }\end{array}$ & - \\
\hline Polystyrene & $\mathrm{MoS}_{2}$ & $\begin{array}{l}0.3,1.6 \& \\
4.5 \mathrm{wt} \%\end{array}$ & $\begin{array}{l}\text { Compression } \\
\text { molding }\end{array}$ & - & $\begin{array}{l}\text { Reduction in } \\
\text { COF \& wear as } \\
\text { filler \% } \\
\text { increases }\end{array}$ & $\begin{array}{l}\text { Improvement in } \\
\text { thermal stability }\end{array}$ \\
\hline \multirow[t]{3}{*}{ PEEK } & Carbon fiber & 30 wt $\%$ & Injection molding & $\begin{array}{l}\text { Increase in tensile } \\
\text { strength }\end{array}$ & $\begin{array}{l}\text { Reduction in } \\
\text { COF }\end{array}$ & - \\
\hline & Glass fiber & $30 w t \%$ & & $\begin{array}{l}\text { Decrease in tensile } \\
\text { strength }\end{array}$ & $\begin{array}{l}\text { Reduction in } \\
\text { COF }\end{array}$ & \\
\hline & $\begin{array}{l}\text { Carbon } \\
\text { fiber + Graphite + PTFE }\end{array}$ & 10 wt $\%$ each & & $\begin{array}{l}\text { Decrease in tensile } \\
\text { strength }\end{array}$ & $\begin{array}{l}\text { Reduction in } \\
\text { COF but } \\
\text { increased wear } \\
\text { rate }\end{array}$ & \\
\hline
\end{tabular}

improvement in tensile strength and hardness with $1 \mathrm{wt} \%$ loading of fillers [63]. Nylon 6/Hytrel blends and MWNT composites were fabricated with the help of melt-mixing by Jogi et al. 15 wt $\%$ loading of hytrel blends shown tensile strength of $40 \mathrm{MPa}$ and $1 \mathrm{wt} \%$ modified MWNT blend shown the tensile strength of $65 \mathrm{MPa}$ in their experimentations [64]. These different reinforcing fillers were also used in other polymer matrices like LDPE, HDPE, ABS, polystyrene, polyester, PEEK, Epoxy, PTFE to improve different properties of polymers as shown in Table 8 [65-76].

Some research on COF and wear analysis described in Table 8 is discussed here for brief detailing. In one research, boric oxide particles were added in PTFE material which reduced the wear rate of the overall composite. This lubrication effect results from the replenishment of lubricous boric acid lamella solid provided to the sliding interface. Regarding PTFE based composite filled with serpentine powder, the normal contact pressure has a significant effect on the friction and wear properties of the composite. With an increase in applied load, the anti-friction performance of the nanocomposite increased gradually, and the wear resistance of the composite was gradually decreased. Sliding velocity is also found as an influencing parameter on the wear performance of the composite. The specific wear rate decreased first and then increased with the increasing rate of sliding velocity. This was due to the decline in mechanical properties under the frictional heat on the contact surface area. PTFE-serpentine nanocomposite showed good selflubricating property due to compact and uniform transfer film generated on the counter face which acted as an excellent solid lubricant. It was also found helpful to reduce the frictional coefficient of the composite. In the case of graphite and $\mathrm{MoS}_{2}$ in the epoxy matrix in dry conditions, it had been found a very impressive effect on reducing the 
friction coefficient and increasing wear resistance when the composite was contacted with A36 steel. Graphite reduced the friction coefficient from 0.48 to 0.25 and the wear volume of the composite drop downed about two orders of magnitude. It found to be effective when added less than $30 \mathrm{vol} \%$. In the case of $\mathrm{MoS}_{2}$, the wear rate decreased but the friction coefficient remained unchanged. In the case of both graphite and $\mathrm{MoS}_{2}$ were present in the composite, the friction coefficient can be as low as 0.25 and the wear volume dropped effectively. Another study reveals that the increased volume fraction of carbon fibers was found effective in tribological properties of epoxy composite reinforced with woven carbon fiber. It led to a decrease in the coefficient of friction and wear loss and the tribo-surfaces became smoother. The coefficient of friction decreased due to carbon fibers acted as a solid lubricant between surfaces. In one study of glass fiber reinforced polyester and a carbon fiber reinforced polyphenylene sulfide, it reveals that the glass fiber reinforced polyester had self-lubricating ability without additional lubricant and carbon fiber reinforced polyphenylene sulfide had a self-protecting ability. Selflubricating ability was found dependent on the load and speed while the self-protecting ability was found independent of load and speed. In the case of glass fiber reinforced polyester, there was a lubricating polymer film which reduced the abrasive nature of the glass fibers while carbon fiber reinforced polyphenylene sulfide created its selfprotecting film which was found independent of the applied load and applied speed, resulted in protection and the composite did not found the wear loss. In another study, glass fibers were used to reinforce an epoxy to which additives of PTFE, graphite, and molybdenum disulfide were used to produce a self-lubricating material. The composite of glass fibers reduced the coefficient of friction value to as low as 0.02 . One research on polystyrene (PS) and $\mathrm{MoS}_{2}$ in oleylamine composites which were prepared by the solvent blending method showed better tribological properties than pure PS. The friction coefficient and wear loss of PS composites decreased with the addition of $\mathrm{MoS}_{2}$ in oleylamine. The $\mathrm{MoS}_{2}$ in oleylamine nanosheets separation and extrusion out of the matrix were found responsible for the friction coefficient reduction. PTFE $+\mathrm{MoS}_{2}+$ glass fibers and PTFE + bronze particle composites were tested for friction coefficient and wear rate in one study. The PTFE with additive $\mathrm{MoS}_{2}$ composite had shown a good coefficient of friction compared to the other one. Unfilled PEEK exhibited a relatively high wear resistance compared with carbon fiber $(30 \%)$, glass fiber $(30 \%)$ and carbon fiber $(10 \%)+$ graphite $(10 \%)+$ PTFE $(10 \%)$ composites. However, it showed the highest friction coefficient of 0.38 in the study when it was contacting with an oscillating chromed steel shaft.
Composite reinforced by carbon fiber and modified by graphite and PTFE as internal lubricants, did show the best self-lubricating behavior under all operating conditions, including varying speeds and loads. However, it significantly reduced its wear resistance. Carbon fiber reinforced PEEK composite showed the best overall tribological characteristics among four test materials. Carbon fibers were superior to glass fibers in enhancing sliding wear resistance.

Table 9 represents the influence of particulate fillers on the mechanical properties of nylon matrices in detail. From Table 9, one chart is drawn for comparing the tensile strength of nylons and nylon particulate composites. It is visible that the micro/nano particulate filler reinforcement increases the tensile strength of nylon matrices by several percentages as shown in Figure 3.

Many researchers have enhanced the tribological performance of nylons by various fillers. Few of the results are shown in Table 10 after COF \& wear resistance testing of materials. Table 10 represents the study of wear rates of different nylon composites. It includes nylon type, reinforcement, test environment (i.e. dry or wet), and the effectiveness of reinforcement on the wear rate of the material. Some symbolic representation of Table 10 is described below:

- $\quad{ }^{+}$The wear rate of copper-acetate-filled nylon was high because the composite transfer film had poor adhesion to the counterface.

- $\Phi$ Transfer film was absent.

- $\Delta$ Some CaS decomposed during sliding and FeS and $\mathrm{FeSO}_{4}$ were produced. No such decomposition was found for $\mathrm{CaF}_{2}$. The bonding strengths of the compounds that decomposed were lower than that of $\mathrm{CaF}_{2}$ which did not decompose. $\mathrm{FeS}$ and $\mathrm{FeSO}_{4}$ formation were responsible for increased adhesion between the composite transfer films.

- $\quad$ In most of the cases, where reinforcement was not effective this was due to the large, aggregated particle formation in the matrix material.

- \# The addition of clay affected the crystallinity of the nanocomposites, which in turn affected the plasticization. Plasticization of the surface by water caused an increase in wear and decreases the coefficient of friction.

- \$ The wear rate of nylon 1010 increased while the friction coefficient decreased in water compare to dry sliding. The hydrolyzation of amide groups and the decrease in bonds of hydrogen between the molecules of nylon 1010 resulted in a high wear rate of nylon in water.

PTFE \& UHMWPE complex solid lubricants improved both frictions and wear behaviors of nylon due to the lower 
Table 9: Effect of particulate fillers on mechanical properties of nylons.

\begin{tabular}{|c|c|c|c|c|c|c|c|c|c|}
\hline \multirow[t]{2}{*}{$\begin{array}{l}\text { Matrix } \\
\text { material }\end{array}$} & \multirow[t]{2}{*}{ Filler(s) } & \multicolumn{2}{|c|}{ Max. tensile strength $(\mathrm{MPa})$} & \multicolumn{2}{|c|}{$\begin{array}{l}\text { Max. flexural } \\
\text { strength (MPa) }\end{array}$} & \multicolumn{2}{|c|}{$\begin{array}{l}\text { Max. Rockwell } \\
\text { hardness }\end{array}$} & \multicolumn{2}{|c|}{$\begin{array}{l}\text { Max. Izod impact- } \\
\text { notched }\left(\mathrm{kJ} / \mathrm{m}^{2}\right)\end{array}$} \\
\hline & & Matrix & Composite & Matrix & Composite & Matrix & Composite & Matrix & Composite \\
\hline Nylon 66 & $\mathrm{Al}_{2} \mathrm{O}_{3}$ microparticles & 75 & 79 for $6 \mathrm{wt} \%$ & 111 & $\begin{array}{l}119 \text { for } \\
6 \mathrm{wt} \%\end{array}$ & 97 & $\begin{array}{l}105 \text { for } \\
8 \mathrm{wt} \%\end{array}$ & 5.1 & 6.02 for $6 \mathrm{wt} \%$ \\
\hline Nylon 6 & $\mathrm{Al}_{2} \mathrm{O}_{3}$ nanoparticles & 60 & 93 for 3 wt $\%$ & - & - & - & - & - & - \\
\hline Nylon 6 & $\begin{array}{l}\text { Talc and wollastonite } \\
\text { microparticles }\end{array}$ & 65 & 78 for $20 w t \%$ & 40 & $\begin{array}{l}90 \text { for } \\
20 \mathrm{wt} \%\end{array}$ & - & - & 10.2 & 12 for $20 w t \%$ \\
\hline Nylon 6 & Clay nanoparticles & 70 & 91 for $5 w t \%$ & 115 & $\begin{array}{l}146.52 \text { for } \\
5 \mathrm{wt} \%\end{array}$ & - & - & $\begin{array}{r}90 \\
(\mathrm{~J} / \mathrm{m})\end{array}$ & $\begin{array}{l}91(\mathrm{~J} / \mathrm{m}) \text { for } \\
5 \mathrm{wt} \%\end{array}$ \\
\hline Nylon 6 & MWNT nanocomposite & 20 & 42 for 1 wt $\%$ & - & - & 60 & $\begin{array}{l}100 \text { for } \\
1 \mathrm{wt} \%\end{array}$ & - & - \\
\hline Nylon 6 & Hytrel blends, MWNT & 39 & $\begin{array}{l}40 \text { for } 15 \text { wt } \% \text { hytrel } \\
\text { blends, } 65 \text { for } 1 \text { wt } \% \\
\text { MWNT }\end{array}$ & - & - & - & - & - & - \\
\hline Nylon 6 & $\begin{array}{l}\text { Boric anhydride } \\
\text { microparticles }\end{array}$ & 52.7 & 62.9 for 2 wt $\%$ & - & - & 116 & $\begin{array}{l}123 \text { for } \\
8 w t \%\end{array}$ & $\begin{array}{l}48.4 \\
(J / m)\end{array}$ & $\begin{array}{l}45.7(\mathrm{~J} / \mathrm{m}) \text { for } \\
6 \mathrm{wt} \%\end{array}$ \\
\hline Nylon 11 & HNT nanoparticles & 41 & 44.6 for 1 wt $\%$ & - & - & - & - & 5.5 & 3.8 for 1 wt $\%$ \\
\hline Nylon 66 & ZrP nanoplatelets & 72.7 & 82.8 for $3 w t \%$ & - & - & - & - & - & - \\
\hline Nylon 66 & GRF & 70.21 & 73.62 for $1 \mathrm{wt} \% \mathrm{GRF}$ & - & - & - & - & - & - \\
\hline
\end{tabular}

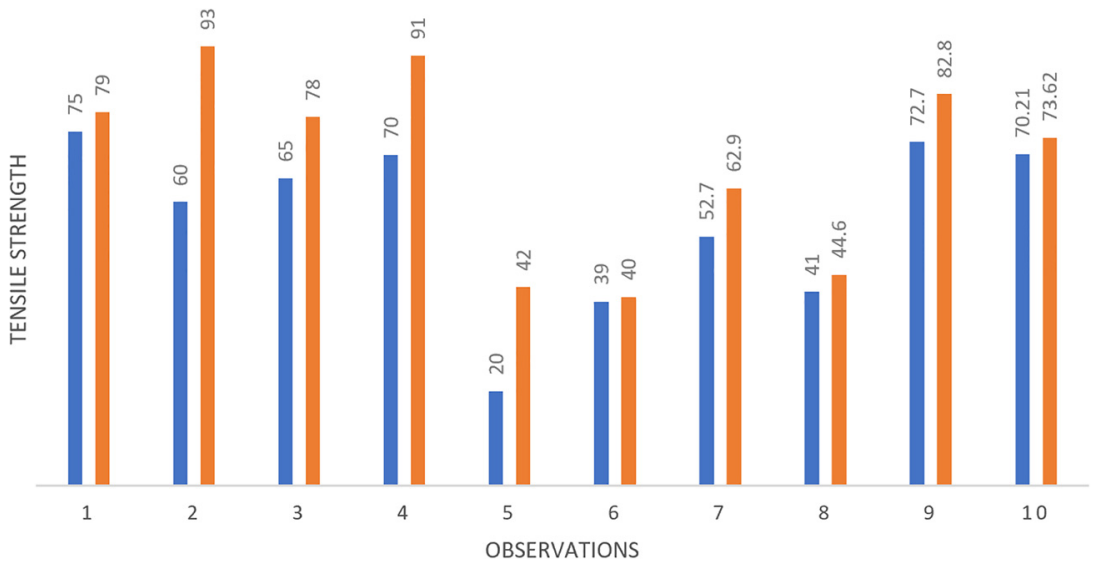

Figure 3: Comparison of the tensile strength of nylons and nylon composites. friction coefficient [116]. Also, internally lubricated glassfiber filled nylon gears showed better performance than nylon gears [117]. Nylon 66 composite exhibited less friction and wear compared to unreinforced when running against steel and aluminum counter faces but when tested against brass, pure nylon 66 exhibited lower wear than the composite had been noted [118]. The characteristics of the different counterface metallic materials and the surface treatment greatly control the wear behavior of nylon 66 and its composites. In one experiment, PTFE filler was found effective on the friction and wear properties of nylon than $\mathrm{MoS}_{2}$ and the main wear mechanisms were fatigue and abrasion had been noted [119].
Nowadays to avoid the use of external lubrication due to several reasons like contamination, degradation of mechanical properties \& absorption, self-lubricated composites are in trends [120-122]. The self-lubrication property of polymer and polymer composite eliminates the requirement of any other external lubrication. Self-lubrication property is advantageous where one cannot use traditional liquid lubrication and where it is almost impossible to reach and do lubrication in a definite time interval. Liquid or grease lubricants are used to minimize friction and wear in the case of metals. When there is an extreme environmental condition like extremely high or low temperatures, vacuum, extreme contact pressure, and absorption (in the 
Table 10: Effect of fillers on tribological properties of nylons.

\begin{tabular}{|c|c|c|c|c|}
\hline Matrix & Reinforcement & $\begin{array}{l}\text { Test } \\
\text { environment }\end{array}$ & Test result & References \\
\hline Nylon 6 & Nano $\mathrm{SiO}_{2}(2 \mathrm{wt} \%)$ & Dry air & Effective (reduction in COF and improvement in wear resistance) & \\
\hline Nylon 66 & PTFE (15 wt\%) & $\begin{array}{l}\text { Dry air } \\
\text { Water }\end{array}$ & $\begin{array}{l}\text { Effective (reduction in COF and improvement in wear resistance) } \\
\text { Reduction in COF }\end{array}$ & 578 \\
\hline Nylon 11 & $\begin{array}{l}\text { CuS, CuO, CuF ( } 35 \text { vol\% } \\
\text { each) } \\
\text { Copper acetate ( } 35 \text { vol\%) }\end{array}$ & Dry air & $\begin{array}{l}\text { Effective (reduction in wear rate) } \\
\text { Not effective }^{+}\end{array}$ & \\
\hline Nylon 6 & Wax (4 wt\%) & Dry air & Effective (reduction in wear rate) & \\
\hline Nylon 11 & Nano silica (15 vol\%) & Dry air & Effective ( $35 \%$ in scratch and $67 \%$ in wear resistance & \\
\hline Nylon 11 & $\begin{array}{l}\mathrm{ZnF}_{2}, \mathrm{ZnS}(35 \text { and } \\
40 \mathrm{wt} \%) \\
\mathrm{PbS}(<35 \mathrm{wt} \%)\end{array}$ & Dry air & $\begin{array}{l}\text { Not effective }{ }^{\Phi} \text { (increased specific wear rate } 11 \text { times and } 15 \text { times } \\
\text { respectively and COF increased } 15-20 \% \text { ) } \\
\text { Effective (reduction in specific wear rate but COF increased } 15-20 \% \text { ) }\end{array}$ & \\
\hline Nylon 11 & CuS (35 vol\%) & Dry air & Effective (reduction in wear rate) & {$[8$} \\
\hline Nylon 11 & $\begin{array}{l}\mathrm{CaS}, \mathrm{CaO}(35 \text { vol\% each) } \\
\mathrm{CaF}_{2}(35 \text { vol\%) }\end{array}$ & Dry air & $\begin{array}{l}\text { Effective (reduction in wear rate) } \\
\text { Not effective }^{\Delta} \text { (increased wear rate) }\end{array}$ & {$[8$} \\
\hline Nylon 66 & $\begin{array}{l}\text { Long carbon nanotubes } \\
\text { (1 wt\%) }\end{array}$ & Dry air & $\begin{array}{l}\text { Effective (reduction in COF but wear rate was increased beyond } \\
110^{\circ} \mathrm{C} \text { ) }\end{array}$ & \\
\hline Nylon 6 & $\begin{array}{l}\text { Glass fiber }(10,20 \& \\
30 w t \%)\end{array}$ & Dry air & Effective (reduction in specific wear rate, lowest @ 30\% fillers) & \\
\hline Nylon 1010 & $\begin{array}{l}\text { ZnO whiskers }(10 \% \& \\
15 \mathrm{wt} \%)\end{array}$ & Dry air & Effective (reduction in COF \& wear) & \\
\hline Nylon 6 & $\begin{array}{l}\text { Wollastonite particles } \\
(5 \% \text { \& } 10 \mathrm{wt} \%)\end{array}$ & Dry air & Effective (reduction in material weight loss due to wear) & \\
\hline Nylon 66 & $\begin{array}{l}\text { Fly ash and silica fume } \\
(5-25 \mathrm{wt} \%)\end{array}$ & Dry air & Effective (reduction in wear rate, best @ 15\% fly ash fillers) & {$[89,9$} \\
\hline Nylon 6 & Copper (2\%) & Dry air & Effective (reduction in COF \& wear) & {$[9$} \\
\hline Nylon 66 & Titanium dioxide $\left(\mathrm{TiO}_{2}\right)$ & Dry air & Effective (reduction in COF \& wear) & {$[9$} \\
\hline $\begin{array}{l}\text { Nylon6/ } \mathrm{TiO}_{2} \\
(95 / 5)\end{array}$ & $\begin{array}{l}\text { PTFE (15 wt\%) } \\
\text { UHMWPE (15 wt\%) } \\
\text { MoS }_{2}(15 w t \%)\end{array}$ & Dry air & $\begin{array}{l}\text { Effective (reduction in COF \& wear) } \\
\text { Effective (reduction in COF \& wear) } \\
\text { Not effective (increasing COF and wear rate) }\end{array}$ & {$[9$} \\
\hline Nylon 66 & $\begin{array}{l}\text { SGF (35wt\%) } \\
\text { SGF (35wt \%) }+\mathrm{MoS}_{2} \\
(2 \text { wt } \%)\end{array}$ & Dry air & Effective (reduction in specific wear rate) & \\
\hline Nylon 6 & Pristine clay (60 wt\%) & Dry air & Not effective ${ }^{\star}$ (worst wear resistance) & {$[9$} \\
\hline Nylon 6 & $\begin{array}{l}\mathrm{Al}_{2} \mathrm{O}_{3}(30 \%) \text {, graphite } \\
(20 \%)\end{array}$ & Dry air & Effective (reduction in COF \& wear) & \\
\hline Nylon 66 & Nano calcium carbonate & Dry air & Effective (reduction in wear rate) & {$[9$} \\
\hline Nylon 6 & $\begin{array}{l}\text { Multiwall carbon nano- } \\
\text { tubes (1 wt\%) }\end{array}$ & Dry air & Effective ( $33.8 \%$ reduction in penetration depth) & \\
\hline Nylon 6 & Nano Cu/Si (0.5\%) & Dry air & $\begin{array}{l}\text { Effective (reduction in COF and wear till } 0.5 \% \text { fillers, after that it } \\
\text { increases) }\end{array}$ & \\
\hline Nylon 6 & Nano clay & Dry air & Effective & [100] \\
\hline Nylon 6 & Glass fiber (30 wt \%) & Dry air & $\begin{array}{l}\text { Effective (reduction in COF and wear till } 30 \% \text { fillers, after that it } \\
\text { increases) }\end{array}$ & [101] \\
\hline Nylon 6 & VGCF (5 wt\%) & Dry air & $\begin{array}{l}\text { Effective (COF decreasing for a small amount of VGCF and then } \\
\text { increasing, wear resistance increasing as the filler content } \\
\text { increasing) }\end{array}$ & {$[10$} \\
\hline Nylon 6 & $\begin{array}{l}\mathrm{SiC}(10 \mathrm{wt} \%)-\mathrm{Al}_{2} \mathrm{O}_{3} \\
(40 \mathrm{wt} \%)\end{array}$ & Dry air & Effective (reduction in wear rate) & {$[10$} \\
\hline Nylon 6 & Carbon fibers (20 wt \%) & Dry air & Effective (reduction in specific wear rate) & {$[104$} \\
\hline Nylon 6 & Graphite $(5,10,15$ wt $\%)$ & Dry air & Effective (reduction in specific wear rate) & [105] \\
\hline Nylon 66 & $\begin{array}{l}\text { Fly ash (15 wt\%) } \\
\text { Silica fume (15 wt \%) }\end{array}$ & Dry air & Effective (reduction in specific wear rate) & [106] \\
\hline Nylon 1010 & Carbon fibers (20 vol\%) & $\begin{array}{l}\text { Dry air } \\
\text { Water }\end{array}$ & $\begin{array}{l}\text { Reduction in COF but the increasing wear rate } \\
\text { Reduction in COF and wear rate }\end{array}$ & [107] \\
\hline Nylon 6 & Polypropylene (30\%) & Dry air & Effective (reduction in COF and wear rate) & \\
\hline
\end{tabular}


Table 10: (continued)

\begin{tabular}{|c|c|c|c|}
\hline Matrix & Reinforcement & $\begin{array}{l}\text { Test } \\
\text { environment }\end{array}$ & Test res \\
\hline & $\begin{array}{l}\text { Nano clay }(2.5,5 \& 7.5 \mathrm{wt} \\
\%)\end{array}$ & & Redu \\
\hline $\begin{array}{l}\text { GFN ( } 30 \% \\
\text { glass fibers) }\end{array}$ & Graphene oxide (0.03\%) & Dry air & Effective $(\sim$ \\
\hline Nylon 11 & $\begin{array}{l}\text { Halloysite nanotube } \\
(1,3,5 \mathrm{wt} \%)\end{array}$ & Dry air & $\begin{array}{l}\text { Effective } \\
\text { specific }\end{array}$ \\
\hline Nylon 66 & $\begin{array}{l}\text { Graphene nanoplatelets } \\
\text { (1 wt\%) }\end{array}$ & Dry air & Effectiv \\
\hline Nylon 6 & Glass fibers & Dry air & Effective \\
\hline Nylon 6 & Organo nano clay (5\%) & Dry air & Effectiv \\
\hline \multirow[t]{2}{*}{ Nylon 66} & $\begin{array}{l}\text { Short glass fibers ( } 20 \mathrm{wt} \\
\%)\end{array}$ & Dry air & \\
\hline & $\begin{array}{l}\text { Short carbon fibers } \\
(20 \mathrm{wt} \%)\end{array}$ & & Effective \\
\hline Nylon 6 & Nano clay (1, $3 \& 5$ wt $\%)$ & Water & Not effec \\
\hline \multicolumn{4}{|c|}{$\begin{array}{l}\text { Symbols: }{ }^{+} \text {, Poor adhesion of composite transfer film to counterface; }{ }^{\Phi} \\
\text { *, agglomeration; }{ }^{\#} \text {, Plasticization of the surface by water; }{ }^{\$} \text {, Hydrolyza }\end{array}$} \\
\hline \multicolumn{4}{|c|}{$\begin{array}{l}\text { case of some polymers), liquid lubricants may not be a } \\
\text { good choice for tribological applications. Liquid lubricants } \\
\text { should not be used where contamination by a liquid is a } \\
\text { problem, at low temperatures where it freezes or become } \\
\text { too viscous to pour, and at high temperatures where it } \\
\text { thermally breaks down. At such conditions, solid lubri- } \\
\text { cants may be the only choice and can help to reduce fric- } \\
\text { tion and wear. Solid lubricants function in the same way, } \\
\text { as they made a low shear strength layer that can shear } \\
\text { easily between two surfaces and avoid direct contact } \\
\text { between surfaces. Solid lubricants can provide low friction } \\
\text { and reduce wear damage between the sliding surfaces. }\end{array}$} \\
\hline
\end{tabular}

\section{Conclusions}

It is visible that the mechanical and tribological properties of nylons are enhanced by the various micro- and nanoparticulates fillers. The coefficient of friction of nylons is further improved and wear rates are decreased by the particulate filler reinforcements. Tensile strength, hardness, and impact strength of nylons are improved by a small number of particulate fillers. There are few cases where particulate fillers were not effective that was due to the clustering of particles in the nylon matrix or due to the excessive humidity and processing temperature effect or due to the improper compounding of matrix and filler materials. Micro- and nanoparticles are having a large surface area to volume ratio i.e., the smaller the particles, the greater will be the surface area to volume ratio. Particle dispersion and distribution play a vital role in determining composite properties. To fabricate a good quality particulate composite, the particle agglomerates must be broken down during processing. A twin-screw extruder is having the advantage of better compounding of thermoplastic polymers and fillers over a single screw in this matter. The clustering of particles is a major issue in the case of nanoparticles. The clustering will result in empty spaces in the matrix and the final composite material can be failed due to mechanical forces. An optimum number of particulate fillers in the composite is desired. The highly filled polymers generally suffer from the clustering of particles, the low adhesive strength of matrix with the particles due to the high amount of fillers and ultimately results in the failure of final composite materials. Metallic fillers in nylons are generally useful in improving a few of the mechanical properties, thermal properties, and wear rates. Metallic compounds like oxides and nitrides are beneficial in enhancing the tribological properties of nylons. Still, the results may vary according to the process and process parameters used for the fabrication of composite. Nylon composite's fabrication process requires special attention to the environmental humidity as it can absorb moisture from the environment which can deteriorate the properties of the final product. Drying of nylon is essential before the compounding of matrix and fillers as well as before injection moulding of products.

The effect of filler particles' size on the tribological behavior of nylon composites is the less explored area. Humidity effect on the tribological behavior of nylon composites is also an important aspect and to understand 
that more research in this area is required. So still there are vast research possibilities available in the area of polymer composites.

Author contributions: All the authors have accepted responsibility for the entire content of this submitted manuscript and approved submission.

Research funding: None declared.

Conflict of interest statement: The authors declare no conflicts of interest regarding this article.

\section{References}

1. Crivelli-Visconti I. Engineering potential of composite materials. Polym. Eng. Sci. 1975, 15, 167-177.

2. Agarwal B. D., Broutman. L. J. Analysis and Performance of Fiber Composites 2nd ed.; John Wiley \& Sons, 1990, 2-16. https://doi. org/10.1017/S0001924000023757.

3. Schwartz M. M. Composite Materials Handbook; McGraw-Hill: New York, 1984.

4. Eckold G. C. Design and Manufacture of Composite Structures; Elsevier: Cambridge, 1994.

5. Hollaway, L. C. The evolution of and the way forward for advanced polymer composites in the civil infrastructure. Construct. Build. Mater. 2003, 365-378. https://doi.org/10.1016/S0950-0618(03) 00038-2.

6. Gürdal Z., Haftka R. T., Hajela P. Design and Optimization of Laminated Composite Materials; John Wiley \& Sons: New York, 1999.

7. Saheb, D. N., Jog J. P. Natural fiber polymer composites: a review. Adv. Polym. Technol. 1999, 351-363. https://doi.org/10.1002/ (SICI)1098-2329(199924)18:4<351::AID-ADV6>3.0.CO;2-X.

8. Miracle D. B., Donaldson S. L., Henry S. D., Moosbrugger C., Anton G. J., Sanders B. R., Hrivnak N., Terman C., Kinson J., Muldoon K., Scott Jr W. W. ASM Handbook; Materials Park, OH: ASM International, 2001, 21, 107-119.

9. Giltrow J. P. Series-composite materials and the designer: Article 4: friction and wear of self-lubricating composite materials. Composites 1973, 4, 55-64.

10. Sviridyonk A. I. Self-lubrication mechanisms in polymer composites. Tribol. Int. 1991, 24, 37-43.

11. Sliney H. E. Solid Lubricants. 1991.

12. Briscoe B. J., Sinha S. K. Wear of polymers. Proc. IME J. J. Eng. Tribol. 2002, 216, 401-413.

13. Rees B. L. Static friction of bulk polymers over a temperature range. Research 1957, 10, 331-338.

14. Lancaster J. K. Relationships between the wear of polymers and their mechanical properties. In Proceedings of the Institution of Mechanical Engineers, Conference Proceedings; Sage UK: London, England: SAGE Publications, Vol. 183(16), 1968; p. 98-106.

15. Olea-Mejia O., Brostow W., Buchman E. Wear resistance and wear mechanisms in polymer+ metal composites. Nanosci. Nanotechnol. 2010, 10, 1-6.
16. Fusaro R. L. Self-lubricating polymer composites and polymer transfer film lubrication for space applications. Tribol. Int. 1990, 23, 105-122.

17. Evans D. C., Senior G. S. Self-lubricating materials for plain bearings. Tribol. Int. 1982, 15, 243-248.

18. Shiao S. J. Dry self-lubricating composites. Compos. B Eng. 1996, 27, 459-465.

19. Li X., Gao Y., Xing J., Wang Y., Fang L. Wear reduction mechanism of graphite and $\mathrm{MoS}_{2}$ in epoxy composites. Wear 2004, 257, 279-283.

20. Xiang D., Shan K. Friction and wear behavior of self-lubricating and heavily loaded metal-PTFE composites. Wear 2006, 260, 1112-1118.

21. Debnath S., Ranade R., Wunder S. L., McCool J., Boberick K., Baran G. Interface effects on mechanical properties of particlereinforced composites. Dent. Mater. 2004, 20, 677-686.

22. Bijwe J., Logani C. M., Tewari U. S. Influence of fillers and fibre reinforcement on abrasive wear resistance of some polymeric composites. Wear 1990, 138, 77-92.

23. Hemanth G., Suresha B., Hemanth R. The effect of hexagonal boron nitride on wear resistance under two and three-body abrasion modes of polyetherketone composites. Surf. Topogr. 2019, 7, 045019.

24. Singh K., Sharma S. Effect of neodymium oxide on microstructure, hardness and abrasive wear behaviour of microwave clads. Mater. Res. Express 2019, 6, 086599.

25. Kim J. H., Jeong J. H., Kim N., Joshi R., Lee G. H. Mechanical properties of two-dimensional materials and their applications. J. Phys. D Appl. Phys. 2019, 52, 083001.

26. Harabi A., Harabi E., Chehlatt S., Zouai S., Karboua N. E., Foughali L. Effect of $\mathrm{B}_{2} \mathrm{O}_{3}$ on mechanical properties of porous natural hydroxyapatite derived from cortical bovine bones sintered at 1,050 C. Desalin. Water Treat. 2016, 57, 5303-5309.

27. Cui, L., Hao, X., Tang, Y., Zheng, Z., Yuan, Y., Lu, A. Effect of $\mathrm{B}_{2} \mathrm{O}_{3}$ on physical properties of LZAS vitrified bond and mechanical properties of diamond composites. Int. J. Refract. Metals Hard Mater. 2015, 52, 50-54.

28. Sharmin N., Parsons A. J., Rudd C. D., Ahmed I. Effect of boron oxide addition on fibre drawing, mechanical properties and dissolution behaviour of phosphate-based glass fibres with fixed 40, 45 and 50 mol\% $\mathrm{P}_{2} \mathrm{O}_{5}$. J. Biomater. Appl. 2014, 29, 639-653.

29. Xu Z., Gao C. In situ polymerization approach to graphenereinforced nylon- 6 composites. Macromolecules 2010, 43, 6716-6723.

30. Liu, H. H., Peng, W. W., Hou, L. C., Wang, X. C., Zhang, X. X. The production of a melt-spun functionalized graphene/poly ( $\varepsilon$-caprolactam) nanocomposite fiber. Compos. Sci. Technol. 2013, 81, 61-68.

31. Ding P., Su S., Song N., Tang S., Liu Y., Shi L. Highly thermal conductive composites with polyamide- 6 covalently grafted graphene by an in situ polymerization and thermal reduction process. Carbon 2014, 66, 576-584.

32. Palabiyik M., Bahadur S. Mechanical and tribological properties of polyamide 6 and high density polyethylene polyblends with and without compatibilizer. Wear 2000, 246, 149-158.

33. Zhang Y., Huang B., Li P., Wang X., Zhang Y. Tribological performance of CuS- $\mathrm{ZnO}$ nanocomposite film: the effect of CuS doping. Tribol. Int. 2013, 58, 7-11. 
34. Du N., Zhao C. Y., Chen Q., Wu G., Lu R. Preparation and characterization of nylon 6/graphite composite. Mater. Chem. Phys. 2010, 120, 167-171.

35. Chung H., Das S. Functionally graded Nylon-11/silica nanocomposites produced by selective laser sintering. Mater. Sci. Eng. A 2008, 487, 251-257.

36. Wang S., Ge S., Zhang D. Comparison of tribological behavior of nylon composites filled with zinc oxide particles and whiskers. Wear 2009, 266, 248-254.

37. Wang J. X., Gu M. Y. Investigation of the influence of $\mathrm{CuO}$ filler and carbon fiber on wear and transfer film of nylon composites. J. Appl. Polym. Sci. 2004, 91, 2397-2401.

38. Gong L., Yin B., Li L. P., Yang M. B. Nylon-6/graphene composites modified through polymeric modification of graphene. Compos. $B$ Eng. 2015, 73, 49-56.

39. Xu C., Jia Z., Wu D., Han Q., Meek T. Fabrication of nylon-6/carbon nanotube composites. J. Electron. Mater. 2006, 35, 954-957.

40. Li D. X., You Y. L., Deng X., Li W. J., Xie Y. Tribological properties of solid lubricants filled glass fiber reinforced polyamide 6 composites. Mater. Des. 2013, 46, 809-815.

41. Botlhoko 0. J., Letwaba L., Bandyopadhyay J., Ray S. S. UVprotection, tribology, and mechanical properties of $\mathrm{ZnO}$ containing polyamide composites. J. Appl. Polym. Sci. 2020, 137, 48418.

42. Singh R., Singh N., Amendola A., Fraternali F. On the wear properties of Nylon6-SiC- $\mathrm{Al}_{2} \mathrm{O}_{3}$ based fused deposition modelling feed stock filament. Compos. B Eng. 2017, 119, 125-131.

43. Lim S. H., Dasari A. Nylon-based polymer nanocomposites. Adv. Polym. Nanocompos. 2012, 238-276. https://doi.org/10.1533/ 9780857096241.2.238.

44. Anandhan S. Recent trends in fly ash utilization in polymer composites. Int. J. Waste Resour. 2014, 4. https://doi.org/10. 4172/2252-5211.1000149.

45. Duan L. L., Ran X. Tribological properties and wear mechanism of copper-graphite composite. Adv. Mater. Res. 2012, 472, 618-621.

46. Chang L., Zhang Z., Zhang H., Schlarb A. K. On the sliding wear of nanoparticle filled polyamide 66 composites. Compos. Sci. Technol. 2006, 66, 3188-3198.

47. Sun H., Li T., Lei F., Yang M., Li D., Huang X., Sun D. Graphite fluoride and fluorographene as a new class of solid lubricant additives for high-performance polyamide 66 composites with excellent mechanical and tribological properties. Polym. Int. 2020, 69, 457-466.

48. Mankotia K., Singh I., Singh R. On effect of almond skin powder waste reinforcement in PA6: rheological, thermal and wear properties. Mater. Today Proc. 2020, 33, 1546-1551.

49. Kamerling S., Schlarb A. K. Magnesium hydroxide-a new lever for increasing the performance and reliability of PA66/steel tribosystems. Tribol. Int. 2020, 147, 106271.

50. Randhawa, K. S.; Patel, A. D. Influence of boric anhydride reinforcement on mechanical properties and abrasive wear of nylon 6. Mater. Res. Express 2020, 7, 055303.

51. Abdelhady S. S., Zoalfakar S. H., Agwa M. A., Ali A. A. Treated basalt fibers reinforced nylon 6, 6/epoxy hybrid nanofibril composites. J. Thermoplast. Compos. Mater. 2020, 0892705720904102. https://doi.org/10.1177/ 0892705720904102 .
52. Salih A. A., Zulkifli R., Azhari C. H. Mechanical and morphological properties of bamboo mesoparticle/nylon 6 composites. Int. J. Mater. Res. 2019, 110, 130-136.

53. Nopparut A., Amornsakchai T. Influence of pineapple leaf fiber and it's surface treatment on molecular orientation in, and mechanical properties of, injection molded nylon composites. Polym. Test. 2016, 52, 141-149.

54. Saxena P., Schinzel M., Andrich M., Modler N. Development of a novel test-setup for identifying the frictional characteristics of carbon fibre reinforced polymer composites at high surface pressure. IOP Conf. Ser. Mater. Sci. Eng. 2016, 149, 012124.

55. Karami P., Shojaei A. Improvement of dry sliding tribological properties of polyamide 6 using diamond nanoparticles. Tribol. Int. 2017, 115, 370-377.

56. Sun H., Fang Z., Li T., Lei F., Jiang F., Li D., Zhou Y., Sun D. Enhanced mechanical and tribological performance of PA66 nanocomposites containing $2 \mathrm{D}$ layered $\alpha$-zirconium phosphate nanoplatelets with different sizes. Adv. Compos. Hybrid Mater. 2019, 2, 407-422.

57. Guglani L., Gupta T. C. Wear and mechanical properties of Nylon 66- $\mathrm{Al}_{2} \mathrm{O}_{3}$ microcomposite. J. Reinforc. Plast. Compos. 2017, 36, 1254-1262.

58. Zheng L. Y., Lau K. T., Zhao L. X., Zhang Y. Q., Hui D. Mechanical and thermal properties of nano- $\mathrm{Al}_{2} \mathrm{O}_{3}$ /nylon 6 composites. Chem. Eng. Commun. 2009, 197, 343-351.

59. Mohamed W. S., Nasr H. E., Gutmann R., Sobh R. A. Effect of CaO nanoparticles on the properties of polyamide 6. J. Egy. Chem. 2015, 58, 365-375.

60. Hasan M. M., Zhou Y., Mahfuz H., Jeelani S. Effect of $\mathrm{SiO}_{2}$ nanoparticle on thermal and tensile behavior of nylon-6. Mater. Sci. Eng. A. 2006, 429, 181-188.

61. Unal H., Mimaroglu A., Alkan M. Mechanical properties and morphology of nylon-6 hybrid composites. Polym. Int. 2004, 53, 56-60.

62. Mohanty S., Nayak S. K. Mechanical, thermal and viscoelastic behavior of nylon 6/clay nanocomposites with cotreated montmorillonites. Polym. Plast. Technol. Eng. 2007, 46, 367-376.

63. Zhang W. D., Shen L., Phang I. Y., Liu T. Carbon nanotubes reinforced nylon- 6 composite prepared by simple meltcompounding. Macromolecules. 2004, 37, 256-259.

64. Jogi B. F., Sawant M., Brahmankar P. K., Ratna D., Tarhekar M. C. Study of mechanical and crystalline behavior of polyamide 6/hytrel/carbon nanotubes (CNT) based polymer composites. Proc. Mater. Sci. 2014, 6, 805-811.

65. Szostak, M., Andrzejewski, J. Thermal properties of polymermetal composites. In ASME 2014 12th Biennial Conference on Engineering Systems Design and Analysis. American Society of Mechanical Engineers Digital Collection, 2014. https://doi.org/ 10.1115/ESDA2014-20506.

66. Ryder M. A., Lados D. A., Iannacchione G. S., Peterson A. M. Fabrication and properties of novel polymer-metal composites using fused deposition modeling. Compos. Sci. Technol. 2018, 158, 43-50.

67. Iqbal M. Z., Mamoor G. M., Bashir T., Irfan M. S., Manzoor M. B. A study of polystyrene-metal powder conductive composites. J. Chem. Eng. 2011, 25, 61-64.

68. Krumova M., Klingshirn C., Haupert F., Friedrich K., Micro hardness studies on functionally graded polymer composites. Compos. Sci. Technol. 2001, 61, 557-563. 
69. Bula K., Jesionowski T. Effect of polyethylene functionalization on mechanical properties and morphology of $\mathrm{PE} / \mathrm{SiO}_{2}$ composites. Compos. Interfac. 2010, 17, 603-614.

70. Burroughs B. R., Kim J. H., Blanchet T. A. Boric acid selflubrication of $\mathrm{B}_{2} \mathrm{O}_{3}$-filled polymer composites. Tribol. Trans. 1999, 42, 592-600.

71. Jia Z., Yang Y. Self-lubricating properties of PTFE/serpentine nanocomposite against steel at different loads and sliding velocities. Compos. B Eng. 2012, 43, 2072-2078.

72. Li X., Gao Y., Xing J., Wang Y., Fang L. Wear reduction mechanism of graphite and $\mathrm{MoS}_{2}$ in epoxy composites. Wear 2004, 257, 279-283.

73. Omrani E., Barari B., Moghadam A. D., Rohatgi P. K., Pillai K. M. Mechanical and tribological properties of self-lubricating biobased carbon-fabric epoxy composites made using liquid composite molding. Tribol. Int. 2015, 92, 222-232.

74. Quintelier J., Samyn P., De Doncker L., Vermeulen J., Tuzolana T., Cardon L., Ragaert K., De Baets P., Degrieck J. Self-lubricating and self-protecting properties of polymer composites for wear and friction applications. Polym. Compos. 2009, 30, 932-940.

75. Sorrentino A., Altavilla C., Merola M., Senatore A., Ciambelli P., lannace S. Nanosheets of $\mathrm{MoS}_{2}$-oleylamine as hybrid filler for self-lubricating polymer composites: thermal, tribological, and mechanical properties. Polym. Compos. 2015, 36, 1124-1134.

76. Wu Z., Jia W., Li Z., Hou K., Ma L., Wang J., Yang S. The effect of $\alpha$ zirconium phosphate nanosheets on thermal, mechanical, and tribological properties of polyimide. Macromol. Mater. Eng. 2020, 305, 2000043.

77. García M., De Rooij M., Winnubst L., van Zyl W. E., Verweij H. Friction and wear studies on nylon-6/ $\mathrm{SiO}_{2}$ nanocomposites. J. Appl. Polym. Sci. 2004, 92, 1855-1862.

78. Mens J. W., De Gee A. W. Friction and wear behaviour of 18 polymers in contact with steel in environments of air and water. Wear 1991, 149, 255-268.

79. Bahadur S., Gong D., Anderegg J. W. The role of copper compounds as fillers in transfer film formation and wear of nylon. Wear 1992, 154, 207-223.

80. Unal H., Mimaroglu A. Friction and wear performance of polyamide 6 and graphite and wax polyamide 6 composites under dry sliding conditions. Wear 2012, 289, 132-137.

81. Petrovicova E., Knight R., Schadler L. S., Twardowski T. E. Nylon 11/silica nanocomposite coatings applied by the HVOF process. II. Mechanical and barrier properties. J. Appl. Polym. Sci. 2000, 78, 2272-2289.

82. Bahadur S., Kapoor A. The effect of $\mathrm{ZnF}_{2}, \mathrm{ZnS}$ and $\mathrm{PbS}$ fillers on the tribological behavior of nylon 11. Wear 1992, 155, 49-61.

83. Bahadur S., Deli G. The transfer and wear of nylon and CuS-nylon composites: filler proportion and counterface characteristics. Wear 1993, 162, 397-406.

84. Bahadur S., Gong D., Anderegg J. Investigation of the influence of $\mathrm{CaS}, \mathrm{CaO}$ and $\mathrm{CaF}_{2}$ fillers on the transfer and wear of nylon by microscopy and XPS analysis. Wear 1996, 197, 271-279.

85. Lee S. M., Shin M. W., Jang H. Effect of carbon-nanotube length on friction and wear of polyamide 6, 6 nanocomposites. Wear 2014, 320, 103-110.

86. Kumar S., Panneerselvam K. Two-body abrasive wear behavior of nylon 6 and glass fiber reinforced (GFR) nylon 6 composite. Proc. Technol. 2016, 25, 1129-1136.
87. Shi-bo W. Tribological properties of nylon 1010 composites filled with zinc oxide whisker in rolling friction with traction. Ind. Lubric. Tribol. 2012, 64, 164-170.

88. Çoban A., Demirer A., Ficici F. Optimization of wear parameters of polyamide- 6 composite materials filled with wollastonite particles. Period. Eng. Nat. Sci. 2014, 2. https://doi.org/10. 21533/pen.v2i1.35.

89. Raja V. L., Kumaravel A. Studies on physical and mechanical properties of silica fume-filled nylon 66 polymer composites for mechanical components. Polym. Polym. Compos. 2015, 23, 427-434.

90. Raja V. L., Kumaravel A., Ramesh M., Karthikeyan T. Effective utilization of industrial waste (flyash) to enhance the properties of polymer composites for mechanical components. J. Ind. Pollut. Control 2013, 29.

91. Konieczny J., Chmielnicki B., Tomiczek A. Evaluation of selected properties of PA6-copper/graphite composite. J. Achiev. Mater. Manuf. Eng. 2013, 60, 23-30.

92. Friedrich K., Zhang Z., Schlarb A. K. Effects of various fillers on the sliding wear of polymer composites. Compos. Sci. Technol. 2005, 65, 2329-2343.

93. You Y. L., Li D. X., Si G. J., Deng X. Investigation of the influence of solid lubricants on the tribological properties of polyamide 6 nanocomposite. Wear 2014, 311, 57-64.

94. Basavaraj E., Ramaraj B. A study on mechanical, thermal, and wear characteristics of nylon $66 /$ molybdenum disulfide composites reinforced with glass fibers. Polym. Compos. 2012, 33,1570-1577.

95. Dasari A., Yu Z. Z., Mai Y. W., Hu G. H., Varlet J. Clay exfoliation and organic modification on wear of nylon 6 nanocomposites processed by different routes. Compos. Sci. Technol. 2005, 65, 2314-2328.

96. Satheeskumar S., Kanagaraj G. Experimental investigation on tribological behaviours of PA6, PA6-reinforced Al 203 and PA6-reinforced graphite polymer composites. Bull. Mater. Sci. 2016, 39, 1467-1481.

97. Itagaki K., Nishitani Y., Kitano T., Eguchi K. Tribological Properties of Nanosized Calcium Carbonate Filled Polyamide 66 Nanocomposites; AIP Publishing LLC. 2016. https://doi.org/10. 1063/1.4942299.

98. Giraldo L. F., Brostow W., Devaux E., López B. L., Pérez L. D. Scratch and wear resistance of polyamide 6 reinforced with multiwall carbon nanotubes. J. Nanosci. Nanotechnol. 2008, 8, 3176-3183.

99. Xu Q., Hu P., Wu D., Li X., Zhang Z. Studies on the mechanical and friction properties of polyamide 6-Cu/Si nanocomposites. J. Macromol. Sci. Part A 2017, 54, 323-327.

100. Gurunathan C., Kirupasankar S., Gnanamoorthy R. Wear characteristics of polyamide nanocomposite spur gears. Proc. IME J. J. Eng. Tribol. 2011, 225, 299-306.

101. Kumar S., Panneerselvam K. Investigations on dry sliding wear behaviour of nylon- 6 and GFR nylon- 6 composites using Taguchi technique. 2018, 25, 89-97.

102. Irisawa T., Takamura T., Momozono S., Kaneko J., Shioya M. Analysis on abrasive wear rate of VGCF/polyamide 6 composite fibers. Tribol. Online 2011, 6, 207-218.

103. Singh R., Singh N., Amendola A., Fraternali F. On the wear properties of Nylon6-SiC- $\mathrm{Al}_{2} \mathrm{O}_{3}$ based fused deposition modelling feed stock filament. Compos. B Eng. 2017, 119, 125-131. 
104. Li J., Xia Y. C. The friction and wear properties of thermoplastic PA6 composites filled with carbon fiber. J. Thermoplast. Compos. Mater. 2010, 23, 337-349.

105. Unal H., Esmer K., Mimaroglu A. Mechanical, electrical and tribological properties of graphite filled polyamide- 6 composite materials. J. Polym. Eng. 2013, 33, 351-355.

106. Loganathan Raja V., Kumaravel A. Comparative study on the wear properties of fly ash and silica fume filled nylon composites. Appl. Mech. Mater. 2014, 592, 1277-1284.

107. Wang J., Gu M. Wear properties and mechanisms of nylon and carbon-fiber-reinforced nylon in dry and wet conditions. J. Appl. Polym. Sci. 2004, 93, 789-795.

108. Kaştan, A., Ünal, H. Abrasive wear behavior of polyamide 6/polypropylene/nanoclay composites. Rev. Rom. Mater. 2018, 48, 185-190.

109. Rajamani G., Paulraj J. Abrasive wear analysis on graphene oxide-based hybrid nanopolymer composites. Surf. Rev. Lett. 2019, 26, 1850156.

110. Sahnoune M., Kaci M., Taguet A., Delbé K., Mouffok S., Abdi S., Lopez-Cuesta J. M., Focke W. W. Tribological and mechanical properties of polyamide-11/halloysite nanotube nanocomposites. J. Polym. Eng. 2019, 39, 25-34.

111. Narayana K. S., Suman K. N., Vikram K. A. Investigation on dry sliding wear behavior of Nylon66/GnP nano-composite. J. Inst. Eng. Series D 2017, 98, 71-78.

112. Senthilvelan S., Gnanamoorthy R. Wear characteristics of injection-moulded unfilled and glass-filled nylon 6 spur gears. Proc. IME J. J. Eng. Tribol. 2004, 218, 495-502.

113. Srinath G., Gnanamoorthy R. Effect of nanoclay reinforcement on tensile and tribo behaviour of Nylon 6. J. Mater. Sci. 2005, 40, 2897-2901.
114. Srinath G., Gnanamoorthy R. Effect of short fibre reinforcement on the friction and wear behaviour of nylon 66. Appl. Compos. Mater. 2005, 12, 369-383.

115. Srinath G., Gnanamoorthy R. Sliding wear performance of polyamide 6-clay nanocomposites in water. Compos. Sci. Technol. 2007, 67, 399-405.

116. Li D., Xie Y., Li W., You Y., Deng X. Tribological and mechanical behaviors of polyamide $6 /$ glass fiber composite filled with various solid lubricants. Scientific World J. 2013, 2013, 320837.

117. Mao K., Hooke C. J., Walton D. The wear behaviour of polymer composite gears. J. Synth. Lubric. 1996, 12, 337-345.

118. Chen Y. K., Modi O. P., Mhay A. S., Chrysanthou A., O'sullivan J. M. The effect of different metallic counterface materials and different surface treatments on the wear and friction of polyamide 66 and its composite in rolling-sliding contact. Wear 2003, 255, 714-721.

119. Xing Y., Zhang G., Ma K., Chen T., Zhao X. Study on the friction and wear behaviors of modified PA66 composites. Polym. Plast. Technol. Eng. 2009, 48, 633-638.

120. singh Randhawa K., Patel A. D. Tribological behaviour of PA6/ diborontrioxide composites. In Journal of Physics: Conference Series. IOP Publishing: Coimbatore, India, Vol. 1706(1), 012124 , August 13-14, 2020.

121. Mistry M., Randhawa K. S. Investigations of the influence of hexagonal boron nitride particulates on mechanical \& tribological properties of PA66. In Journal of Physics: Conference Series, IOP Publishing, Coimbatore, India, Vol. 1706(1), 012180, August 13-14, 2020.

122. Randhawa K. S., Patel A. D. Enhancing tribo-mechanical properties \& thermal stability of PA6 by h-BN fillers. E-Polymers 2020, 20, 733-745. 